\title{
Decolourisation of Textile Dyesand Biological Stains by Bacterial Strains Isolated From Industrial Effluents
}

\section{Sanchita Choubey ${ }^{1}$, VidhyaJadhav ${ }^{2,}$ Bhushan Talele $^{3}$ And Suchitra Godbole ${ }^{4}$}

\author{
${ }^{1,2,3,4}$ Department of Microbiology, Dr. D. Y. Patil Arts, Commerce and Science College,
} Sant Tukaram Nagar, Pimpri, Pune, Maharashtra 411018, India

\begin{abstract}
The color removal of textile wastewater is a major environmental concern. Color can be removed from wastewater by Physico-chemical methods such as adsorption, irradiation, ion exchange, oxidative process, ozonation, coagulation have been used to decolorize textile effluents, but these methods are costly, inefficient and sometimes produce hazardous by-product, it also affects the environment during the degradation process. The effluents discharged by different industries contain a high range of physico-chemical parameters like conductivity, hardness, alkalinity, COD, TSS, nitrates, nitrites, cations and anions. The effluent which is untreated is one of the major sources of consumed metal dyes, phenol, aromatic amines. Several aromatic amines are known mutagens and carcinogens to human beings. Among low cost,
\end{abstract}

Key WordsTextile dye, Effluent, Decolourization, Bioremediation and Bacteria

\section{Introduction}

Dyes make the world more beautiful through colored substances, but on the other hand they represent a serious pollution problem for the environment. Almost one million tons of dyes are annually produced in the world. Dyes are the most common synthetic colorants released to the environment via textile, pharmaceutical and chemical industries. Many of them may be carcinogenic to humans as well as to animals. The discharge of dyes in water bodies is problematic not only for aesthetic reasons, but also because viable alternatives, available for effluent treatment and decolourization, the biological systems are recognized.The present study was undertaken to explore with the Textile dyes effluents\&Biological stains degraded by the bacterial strains isolated from the effluent sample.Phytotoxicity of the textile dyes was estimated by measuring the relative changes in seed germination of plants. Radicle and Plumule growth (length) were recorded after 6 days of exposure to different concentrations of dyes. Toxicity of dye was reduced after decolourization. This property of these bacterial isolates shows a potential that can be utilized for the bioremediation of various textile industrial effluents thus saving the ecosystem from harmful effects of various dyes.

dyes and their cleavage products (aromatic amines) are carcinogenic [1].

Nowa days, water pollution has become a matter of great concern in our society. Most of the water pollutions are related to the industrial effluents. Textile industry is the one of the most important industry all over the world and this industry uses large volumes of water in wet processing operations and thereby, generates substantial quantities of wastewater containing large amounts of dissolved dyestuffs and other products. Water is 
essential for survival and existence of life on planet earth. The waste water and sewage are released from the industries that wastes are entering into the water bodies, it is one of major source of environment toxicity and it also affects the soil micro flora and aquatic ecosystem [2, 3]. The most environmental problem faced due to the textile dyeing industry is that the industry produces large volumes of high strength of aqueous waste effluents.

The colored effluents discharged from textile processing and dye-manufacturing industries contain a significant amount of unreacted dyes. Especially in textile industries produced more than $70 \%$ of the total quantity of waste in India [4]. India is the second largest exporter of dyestuffs and intermediates after China. The textile industry accounts for the largest consumption of dyestuffs, at nearly $80 \%$. Industrialization is vital to a nation's economy because it serves as a vehicle for development. However, there are associated problems resulting from the introduction of industrial waste products into the environment. Many of these products are problematic because of persistence (low biodegradability) and toxicity. The

\section{Materialsand Methods}

Effluent sample was collected in clean plastic can from the vicinity of Pulgam Textiles, Solapur, Maharashtra, India. Biological stains- Methylene

\subsection{Physico-chemical property analysis:[9]}

The collected effluent samples were analyzed to determine its physico- chemical parameters. The various parameters viz., Temperature, $\mathrm{pH}$, Colour, Odour, Total dissolved solid (TDS), Total

\subsection{Isolation of dye degrading bacterial isolates from dye effluent:[10]}

The bacterial isolates present in the textile dye effluent were isolated by enriching the sample with inorganic salts and Glucose as a carbon source along with $25 \mathrm{ppm}$ of Red and Blue dye each.The enrichment broth was incubated at $28 \pm 2^{\circ} \mathrm{C}$ for 1 week at static conditions. The enriched broth was plated on sterile Minimal medium agar plates by Serial dilution (Pour plate) technique. In this

\section{ISSN 2455-6378}

effluent which is untreated is one of the major sources of consumed metal dyes, phenol, aromatic amines, several aromatic amines are known mutagens and carcinogens to human beings [5]. Dyes also affect internal organ like kidney, liver, gastrointestinal tract [6].

There are various microorganisms found in the contaminated environment, have potential to decolorize and even completely mineralize many dyes from the wastewater efficiently under certain environmental conditions. Have been reported by various researchers [7]. Several bacterial strains that can aerobically decolourize dyes have been isolated during the past few years. Many of these strains require organic carbon sources, as they cannot utilize dye as growth substrate. Biodegradation using microorganisms are gaining importance as it is cost effective, environmental friendly and produces less sludge [8].

Hence the present study was conducted to isolate the potential dye/stains (industrial as well as commonly used laboratory stains) degrading bacteria from industrial effluents and study their Dye degradation potential.

Blue, Malachite Green, Crystal Violet and Safranin were collected from the Microbiology Department of D. Y. Patil ACS College, Pimpri, Pune.

suspended solids (TSS), Chemical oxygen demand (COD), Biological oxygen demand (BOD), Dissolved Oxygen (DO) were analysed in the laboratory by the standard protocols.

method, $1 \mathrm{ml}$ of enriched broth was thoroughly mixed with $9 \mathrm{ml}$ of sterile distilled water, and then it was serially diluted by following standard procedure up to concentration of $10^{-6}$. Then, $1 \mathrm{ml}$ of serially diluted broth from each concentration of samples were transferred to sterile petriplates and evenly distributed throughout the plates and sterile unsolidified Minimal Agar was poured and it was 
allowed to solidify. The Minimal agar plates were incubated at $28 \pm 2^{\circ} \mathrm{C}$ for 24 hours. After incubation, the bacterial colonies were isolated and purified from the plates. The well screened cultures were transferred to agar slant and stored at $4{ }^{\circ} \mathrm{C}$ for

\subsection{Decolourization test:}

\subsubsection{Decolorization of Textile Dyes:[11]}

The isolated bacteria were further tested to check their ability to decolorize the textile dyes. The bacterial isolates were grown in two different media-Medium A- supplemented with $1.0 \mathrm{ml}$ of 10 $\%$ Glucose and medium B- supplemented with 1.0 $\mathrm{ml}$ of $10 \%$ Casamino acids. Each medium was supplemented with increasing concentrations of the further study.All bacterial isolates were identified based on their colony characteristics, morphological characteristics and biochemical reactions.

Percentage decolourization $=$ Initial O.D - Final O.D. X 100

\section{Initial O.D.}

\subsubsection{Decolorization of Biological Stains:[12]}

The decolourization capacity of isolatedbacteriawas also studied using biological stain solutionsMethylene Blue, Malachite Green, Safranin\& Crystal Violet of different concentration. Each flask containing bacterial isolates along with distilled water was supplemented with increasing concentrations of the stain $(50 \mathrm{ppm}, 100 \mathrm{ppm}, 150$ dye (50 ppm, $100 \mathrm{ppm}, 150 \mathrm{ppm}$ and $200 \mathrm{ppm}$ ). The flasks were incubated at $28 \pm 2^{\circ} \mathrm{C}$ for 24 hours under static conditions. After incubation the solution was centrifuged at $5000 \mathrm{rpm}$ for 10 minutes. The optical density was taken at the appropriate wavelength $(\lambda \max )$. Percentage decolourization was calculated by the formula-

Percentage decolourization $=\underline{\text { Initial O.D. }- \text { Final O.D. X } 100}$ Initial O.D.

\subsubsection{Bioassay for dye toxicity by Seed germination test-[13, 14]}

In this experiment, the effect of four different concentrations of dyes were evaluated on germination of seeds of 3 plants: Triticumspp., Vigna radiate and Brassica juncea. The seedswere germinated in sterile Petri dishes. Three sets of thirty seeds each of Triticumspp., Vigna radiate and Brassica juncea were treated with $2 \mathrm{ml}$ of dye solutions (concentrations of 500 ppm, 1000 ppm, $5000 \mathrm{ppm}$ and 10,000 ppm respectively). The range ppm and $200 \mathrm{ppm})$. The flasks were incubated at 28 $\pm 2^{\circ} \mathrm{C}$ for 24 hours under static conditions. After incubation the solution was centrifuged at 5000 rpm for 10 minutes. The optical density was taken at the appropriate wavelength $(\lambda \max )$. Percentage decolourization was calculated by the formula- 
In another independent experiment, $100 \mathrm{ppm}$ of the dye which was more decolorized by the bacteria isolated from the effluent sample was used to check the toxicity of the biologically treated dye on the germination of the seeds. The inoculations were made as follows: (a) $100 \mathrm{ppm}$ of dye in plain water, (b)100 ppm of dye in plain water \& autoclaved, (c) $100 \mathrm{ppm}$ of dye in plain water, inoculated, incubated at $28^{\circ} \mathrm{C}$ for 2 weeks, (d) centrifuged, 100 ppm of dye in plain water, inoculated, incubated at $28^{\circ} \mathrm{C}$ for 2 weeks, autoclaved.

The seeds were germinated in sterile Petri dishes, layered with sterile circular filter paper diameter-

\section{Results and Discussion}

The dye effluents were collected from dying industry in Maharashtra, India. These industries discharge the brownish red colored effluents with dyes and toxic compounds into the open environment. The collected sample was analyzed to determine their physico - chemical characteristics. These characteristics were compared with the recommended level of NEQS was showed Table-1 [15]. According to the results, the temperature of the effluent was $38.8^{\circ} \mathrm{C}$, low as compared to the standards. The maximum $\mathrm{pH}$ range was recorded 5.5 which indicate acidic nature of the sample. The value of total dissolved solid was obtained 4440 10cm). 30 Seeds each of Triticumspp., Vigna radiate and Brassica juncea were irrigated with 2 $\mathrm{ml}$ of samples described in the table above. Every day $2 \mathrm{ml}$ of the same dye solution was applied to the surface of the filter paper. Each treatment was replicated three times. Seeds germinated in petri dishes containing distilled water wereused as a control. All dishes were kept at room temperature $\left(28 \pm 2^{\circ} \mathrm{C}\right)$ for 6 days. Germination of seeds was daily recorded. At the end of the germination experiment, the shooting percentage and root length of seedlings were measured.

$\mathrm{mg} / \mathrm{l}$, which indicated that the sample contained high concentration of dissolved solids which would affect the quality of freshwater and subsequently cause harm to aquatic life. The total suspended solid was recorded as $320 \mathrm{mg} / \mathrm{l}$. The chemical oxygen demand of the sample was $763 \mathrm{mg} / \mathrm{l}$ which is much higher than maximum recommended limit of NEQS. And the biological oxygen demand was recorded as $273 \mathrm{mg} / \mathrm{l}$ which was comparatively higher than the recommended value. Thus, the results showed that the textile effluent sample needed to be treated before discharging it into the environment.

\begin{tabular}{|c|l|c|c|}
\hline Sr.No & Parameters & Dye Effluent Sample & NEQS* \\
\hline 1 & Temperature & 38.8 & 40 \\
\hline 2 & $\mathrm{pH}$ & 5.5 & $6-9$ \\
\hline 3 & Colour & Brownish red & Colorless \\
\hline 4 & Odour & Unpleasant & Odourless \\
\hline 5 & TS $(\mathrm{mg} / \mathrm{l})$ & 4760 & 4500 \\
\hline 6 & $\mathrm{TSS}(\mathrm{mg} / \mathrm{l})$ & 320 & - \\
\hline 7 & $\mathrm{TDS}(\mathrm{mg} / \mathrm{l})$ & 4440 & 3800 \\
\hline 8 & $\mathrm{DO}(\mathrm{mg} / \mathrm{l})$ & 5.4 & - \\
\hline 9 & $\mathrm{BOD}(\mathrm{mg} / \mathrm{l})$ & 273 & $156-400$ \\
\hline 10 & $\mathrm{COD}(\mathrm{mg} / \mathrm{l})$ & 763 & \\
\hline
\end{tabular}

NEQS- National Environmental Quality Standards

Table -1: Physico - chemical characterization of textile dye effluent samples

Identification of isolates obtained from effluent samples were done by morphological characterization, microscopically by Gram staining, and various biochemical tests recommended in the Bergey's Manual of
Determinative Bacteriology (Table 2) [16]. According to the tests, three organisms in Isolated may be Bacillus spp., Klebsiella spp., Pseudomonas spp. 


\begin{tabular}{|c|c|c|c|c|}
\hline Sr.No & $\begin{array}{c}\text { Colony \& } \\
\text { MorphologicalCharacters }\end{array}$ & Isolate 1 & Isolate 2 & Isolate 3 \\
\hline 1 & Size & $1-2 \mathrm{~mm}$ & $2 \mathrm{~mm}$ & $2.5 \mathrm{~mm}$ \\
\hline 2 & Shape & Irregular & Regular & Circular \\
\hline 3 & Colour & Cream & Cream & Cream \\
\hline 4 & Margin & Regular & Entire & Irregular \\
\hline 5 & Elevation & Low convex & Low convex & Oplat \\
\hline 6 & Opacity & Opaque & Opaque & Butyrous \\
\hline 7 & Consistency & Butyrous & Mucoid & Gram negative rods \\
\hline 8 & Gram character & Gram negative rods & Gram positive rods & Non-motile \\
\hline 9 & Motility & Motile & Non-motile & \\
\hline
\end{tabular}

2 (a) Colony \& Morphological characteristics

\begin{tabular}{|c|c|c|c|c|}
\hline Sr.No & Biochemiacal test & Isolate 1 & Isolate 2 & Isolate 3 \\
\hline 1 & $\begin{array}{c}\text { Sugar } \\
\text { fermentation }\end{array}$ & & Positive & Positive \\
& Glucose & Negative & Negative & Positive \\
& Lactose & Negative & Positive & Positive \\
& Maltose & Negative & Positive \\
& Sucrose & Negative & Positive & Positive \\
& Mannitol & Positive & Positive & Positive \\
& Arabinose & Negative & Positive & Negative \\
\hline 2 & Catalase & Positive & Positive & Negative \\
\hline 3 & Oxidase & Positive & Kacillus spp. & \\
\hline 5 & Nitrate reduction & Positive & & \\
\hline
\end{tabular}

2 (b) Biochemical tests for the isolates( for sugar fermentation mention Acid/gas or only acid positive)

Table 2: Morphological, Biochemical and Physiological Characterization of the Microorganism 2 (a) Colony \& Morphological characteristics 2 (b) Biochemical tests for the isolates

The isolates were checked for their dye decolourization potential by growing them in Medium A and Medium B (Sterile Minimal broth containing Glucose and Sterile Minimal broth containing Casamino acids) containing various concentrations of the textile dye. It was seen that Pseudomonas spp., Bacillus spp., Klebsiella spp. all the threeorganisms could effectively decolorize the dye when grown in Medium B. The decolourization in Medium A was less in comparison with Medium B when the absorbance was checked suggesting that the dyes may be acting as Nitrogen source in the medium supplemented with glucose acting as Carbon source (Fig1).Highest percentage decolourization was shown by Pseudomonas spp. when growninMedium B in Pigment Red 23 Dye as compared with Violet blue dye and other isolates (Table 3). 
ISSN 2455-6378

\begin{tabular}{|c|c|c|c|c|c|c|c|c|}
\hline \multirow{2}{*}{$\begin{array}{l}\text { Si } \\
. \mathbf{N} \\
\mathbf{o}\end{array}$} & \multirow{2}{*}{$\begin{array}{c}\text { Name of the } \\
\text { dye }\end{array}$} & \multirow{2}{*}{$\begin{array}{l}\Lambda \max \\
(\mathbf{n m})\end{array}$} & \multirow[t]{2}{*}{ Isolates } & \multirow[t]{2}{*}{ Media } & \multicolumn{4}{|c|}{ Percentage Decolorization } \\
\hline & & & & & 50ppm & 100ppm & 150ppm & 200ppm \\
\hline \multirow{8}{*}{1} & \multirow{8}{*}{ Red dye } & \multirow{8}{*}{680} & \multirow{3}{*}{$\begin{array}{c}\text { Pseudomonas } \\
\text { Spp }\end{array}$} & Media A & 79.4 & 75 & 69.2 & 57 \\
\hline & & & & & & & & \\
\hline & & & & Media B & 93.68 & 84.2 & 78.90 & 70.11 \\
\hline & & & \multirow{3}{*}{$\begin{array}{c}\text { Klebsiella } \\
\text { spp }\end{array}$} & Media A & 78 & 70.2 & 56 & 45.3 \\
\hline & & & & & & & & \\
\hline & & & & Media B & 90.42 & 87.42 & 76.53 & 56.40 \\
\hline & & & \multirow[t]{2}{*}{ Bacillus spp } & Media A & 63.3 & 44.53 & 21.53 & 13.40 \\
\hline & & & & Media B & 84.2 & 78.4 & 68.9 & 56.3 \\
\hline & \multirow{7}{*}{$\begin{array}{c}\text { Violet Blue } \\
\text { dye }\end{array}$} & \multirow{7}{*}{420} & & & & & & \\
\hline \multirow{6}{*}{2} & & & \multirow{2}{*}{$\begin{array}{c}\text { Pseudomonas } \\
\text { spp }\end{array}$} & Media A & 45.3 & 38.3 & 21.2 & 13.3 \\
\hline & & & & Media B & 78.1 & 69.13 & 58.53 & 45.99 \\
\hline & & & \multirow[t]{2}{*}{ Klebsiella spp } & Media A & 35.3 & 23.7 & 18.3 & 12.3 \\
\hline & & & & Media B & 56.3 & 45.8 & 38.2 & 29.2 \\
\hline & & & \multirow[t]{2}{*}{ Bacillus spp } & Media A & 68.7 & 68.53 & 56.2 & 45.2 \\
\hline & & & & Media B & 23.4 & 12.52 & 6.23 & 1.2 \\
\hline
\end{tabular}

Table 3: Decolourization \% of textile dye effluents by bacterial isolates
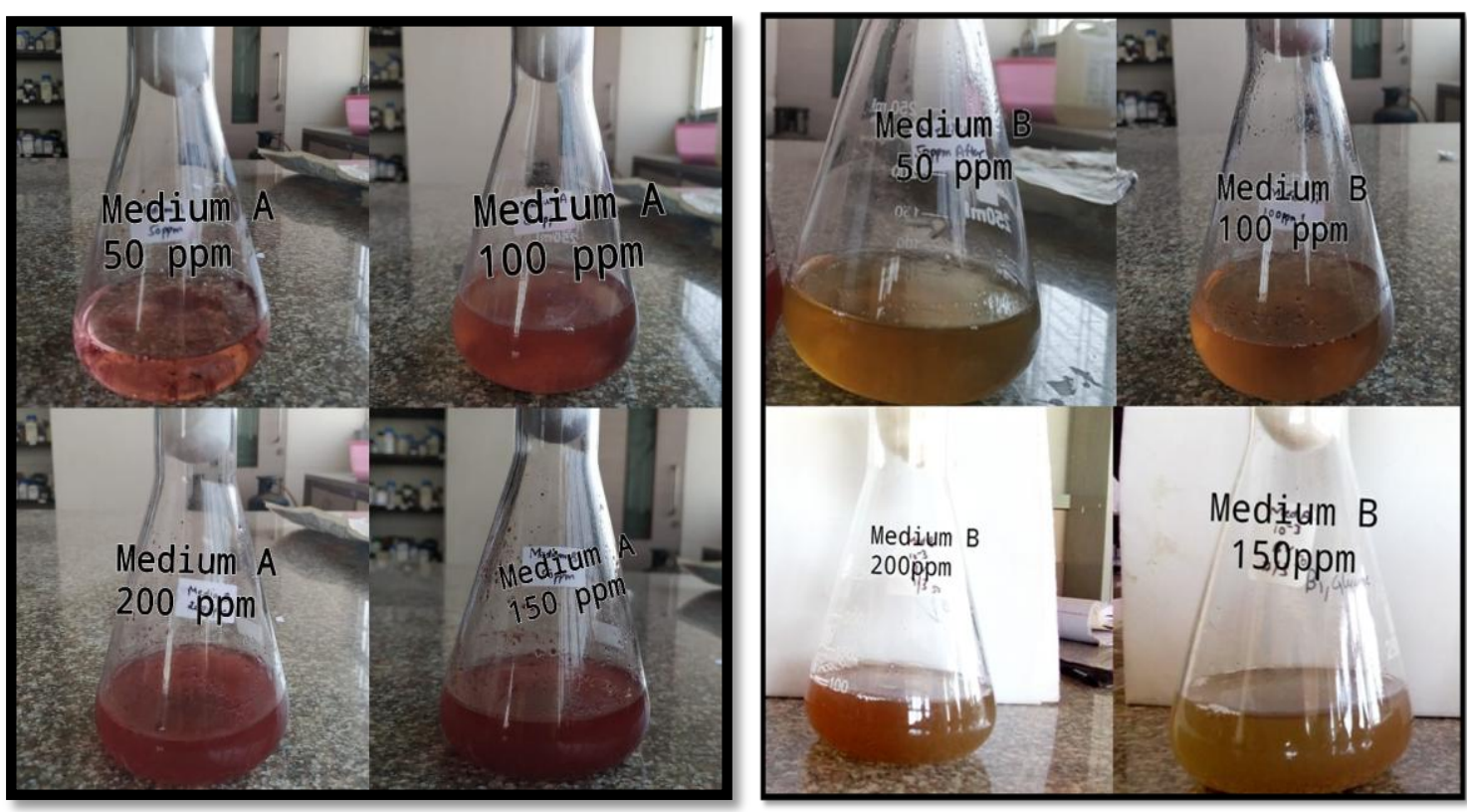

(b) Decolorisation of Textile Red Dyes by Isolates at different concentration in medium A \& B 

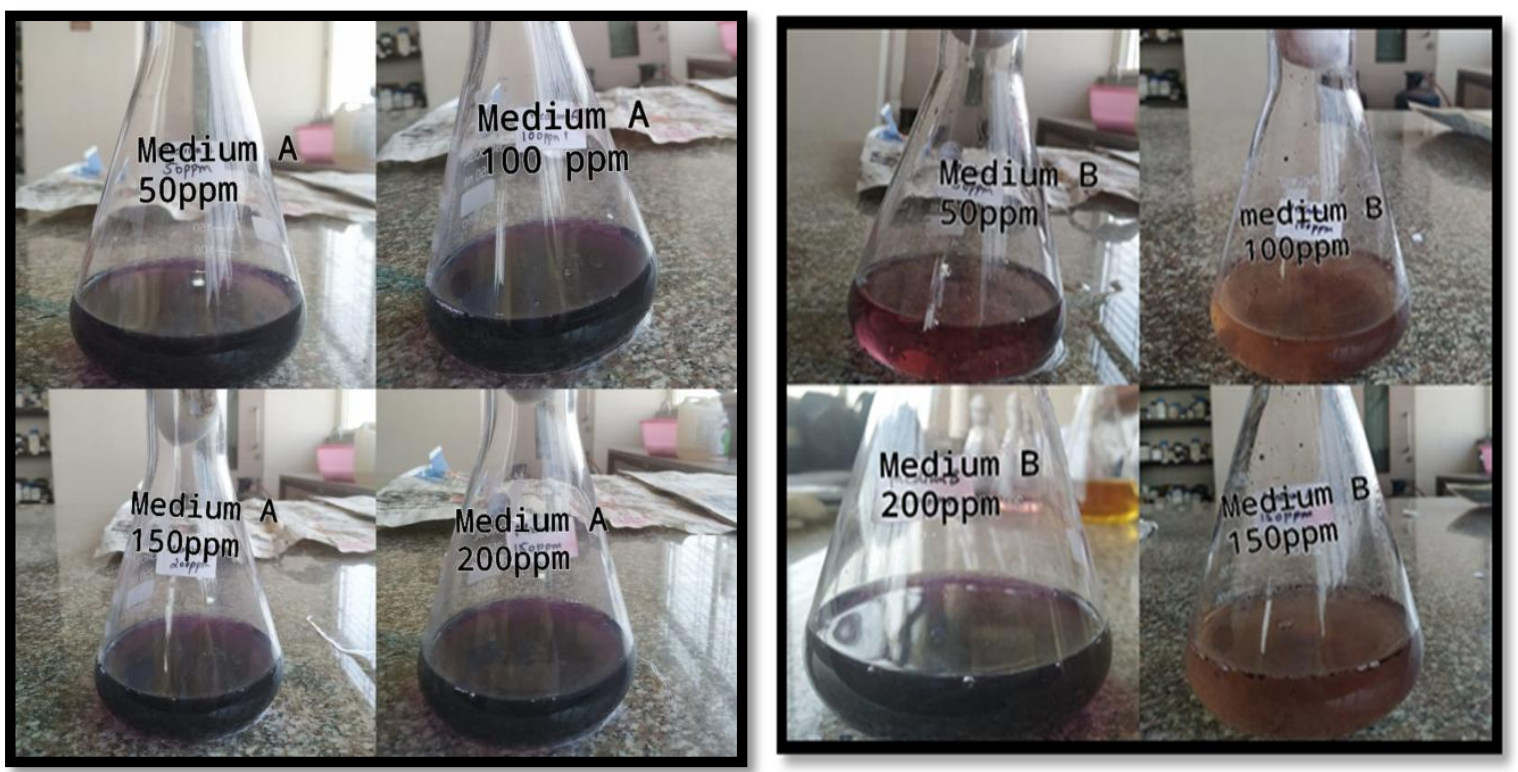

(b) Decolorisation of Textile Violet Blue Dyes by Isolates at different concentration in medium A \& B

Fig 1: Decolorisation of Textile Dyes by Isolates at different concentration in medium A \& B (a) Red Dye (b) Violet Blue Dye

The dye decolourization capacity of Pseudomonas spp was studied using biological stain solutionsMethylene Blue, Malachite Green, Saffranine\& Crystal Viole (Table 4). It was found that
Pseudomonas spp was able to decolorize biological stains of 50ppm and 100ppm concentration only.And among the stains used Malachite green was decolorized more.

\begin{tabular}{|c|l|c|c|c|}
\hline Sr.No & Stain & \multirow{2}{*}{$\mathbf{m a x}(\mathbf{n m})$} & \multicolumn{2}{|c|}{ Percentage Decolorisation } \\
\cline { 3 - 4 } & & & $\mathbf{5 0 p p m}$ & $\mathbf{1 0 0} \mathbf{p p m}$ \\
\hline 1 & Methylene Blue & 570 & 75.86 & 60.13 \\
\hline 2 & Malachite Green & 570 & 77.99 & 60.98 \\
\hline 3 & Safranin & 450 & 40.50 & 49.35 \\
\hline 4 & Crystal Violet & 520 & 69.5 & 40.50 \\
\hline
\end{tabular}

Table 4: Percentage decolourization of Biological stains with Pseudomonas spp after 24 hours

The bioassay for dye toxicity in this study was based on measuring the effect of dye (Red dye) on seed germination, plant shooting and root elongation. The phytotoxicity of different soluble textile dyes was estimated by measuring the relative changes of the mentioned plant parameters using Vigna radiate (whole moong), Triticum spp. (Wheat) and Brassica juncea (Mustard seeds) seeds as test plants. The results show (Table 5) that high concentrations of dyes were more toxic to seed germination as compared with the lower concentrations. The results of this study suggest that while the exposure of seeds to low concentration of dye during germination were less toxic to seed germination as compared with the higher concentrations, the low concentration of the dye could adversely affect the shooting percent significantly (Fig 2). 


\begin{tabular}{|c|c|c|c|c|c|}
\hline Sr.No & Seed Type & Dye Concentration & $\%$ Germination & $\begin{array}{c}\text { Average Shoo1 } \\
\text { length }(\mathrm{cm})\end{array}$ & $\begin{array}{c}\text { Average } \\
\text { Root length } \\
(\mathrm{cm})\end{array}$ \\
\hline \multirow[t]{5}{*}{1} & \multirow[t]{5}{*}{ Triticumspp (Wheat)) } & Control & $100 \%$ & 5.45 & 9.99 \\
\hline & & $500 \mathrm{ppm}$ & $100 \%$ & 5.02 & 8.76 \\
\hline & & $1000 \mathrm{ppm}$ & $100 \%$ & 3.89 & 4.87 \\
\hline & & 5000 ppm & No germination & -- & -- \\
\hline & & $10,000 \mathrm{ppm}$ & No germination & -- & -- \\
\hline \multirow[t]{5}{*}{2} & \multirow{5}{*}{$\begin{array}{l}\text { Brassica juncea(Mustard } \\
\text { seeds) }\end{array}$} & Control & $100 \%$ & 5.88 & 4.95 \\
\hline & & $500 \mathrm{ppm}$ & $100 \%$ & 4.98 & 4.23 \\
\hline & & $1000 \mathrm{ppm}$ & $100 \%$ & 4.78 & 3.53 \\
\hline & & $5000 \mathrm{ppm}$ & $60 \%$ & 2.11 & 2.45 \\
\hline & & $10,000 \mathrm{ppm}$ & $40 \%$ & 1.11 & 1.45 \\
\hline \multirow[t]{5}{*}{3} & \multirow{5}{*}{$\begin{array}{l}\text { Vignaradiata(Moong } \\
\text { seeds) }\end{array}$} & Control & $100 \%$ & 5.00 & 4.92 \\
\hline & & 500 & $100 \%$ & 4.53 & 4.00 \\
\hline & & 1000 & $100 \%$ & 4.18 & 3.64 \\
\hline & & 5000 & $100 \%$ & No shooting & 2.98 \\
\hline & & 1000 & $100 \%$ & No shooting & 2.45 \\
\hline
\end{tabular}

Table 5: Comparison between \% germination, shoot and root length of different seeds at different dye concentrations
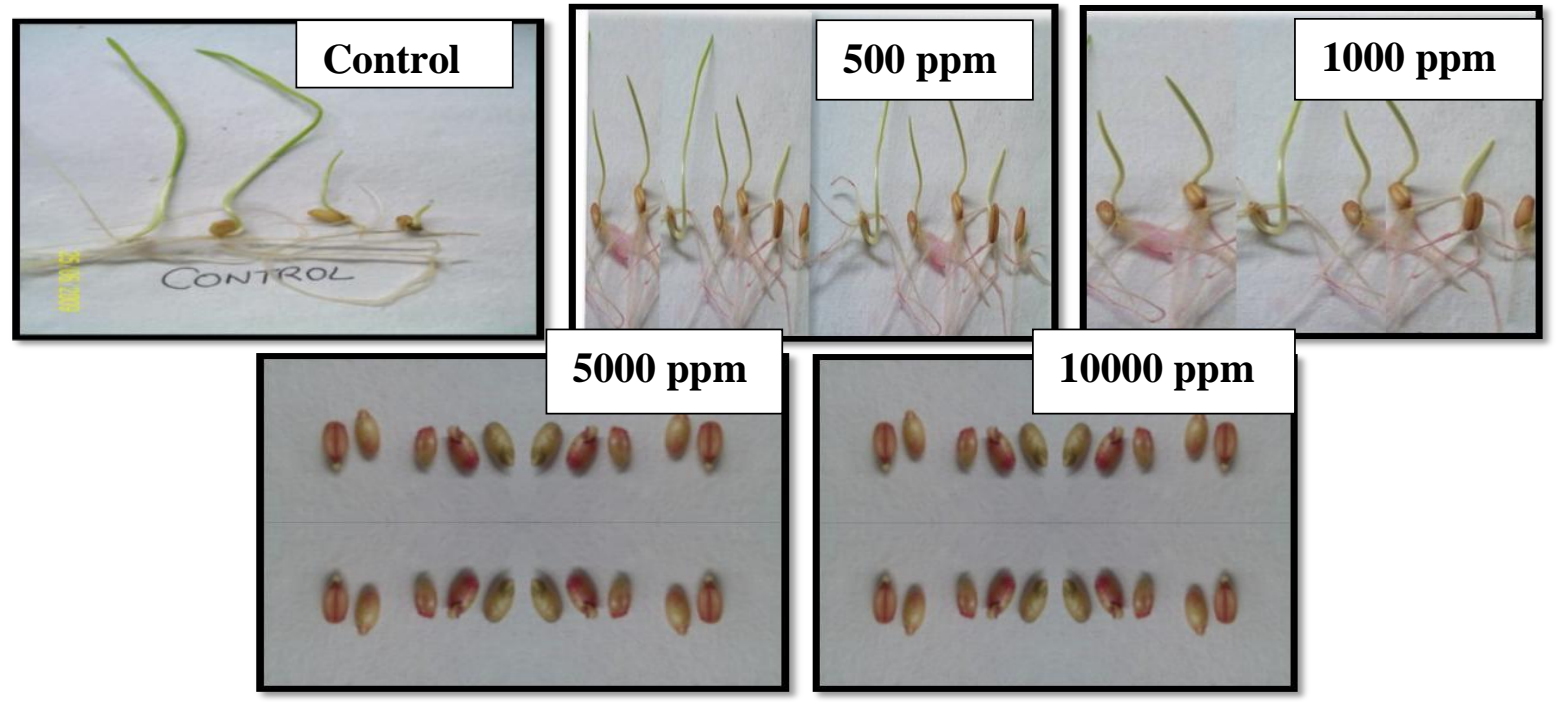

(a) Effect of textile dye on Triticum spp (Wheat) germination 

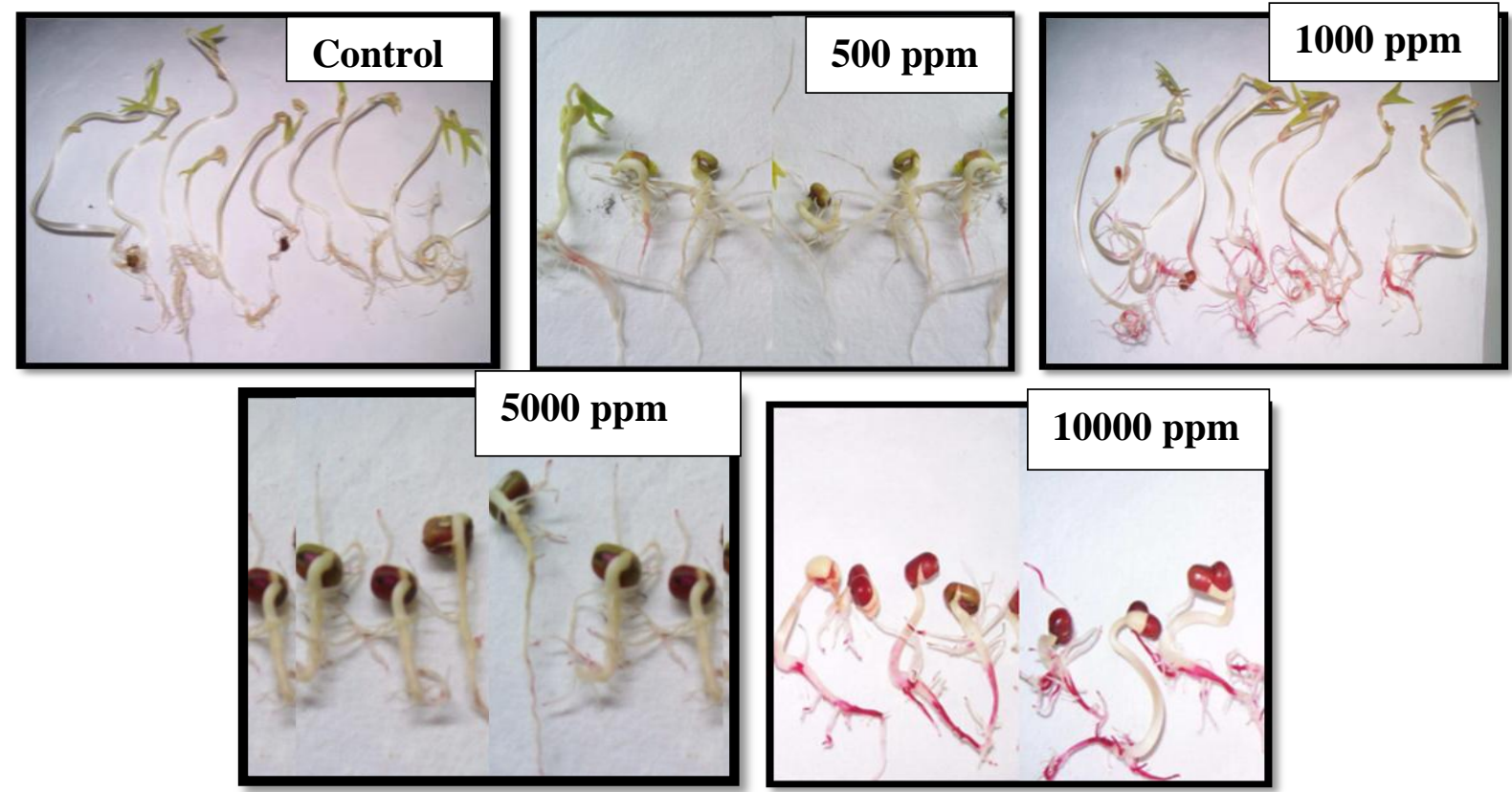

(b) Effect of textile dye on Vigna radiata(Moong) seed germination
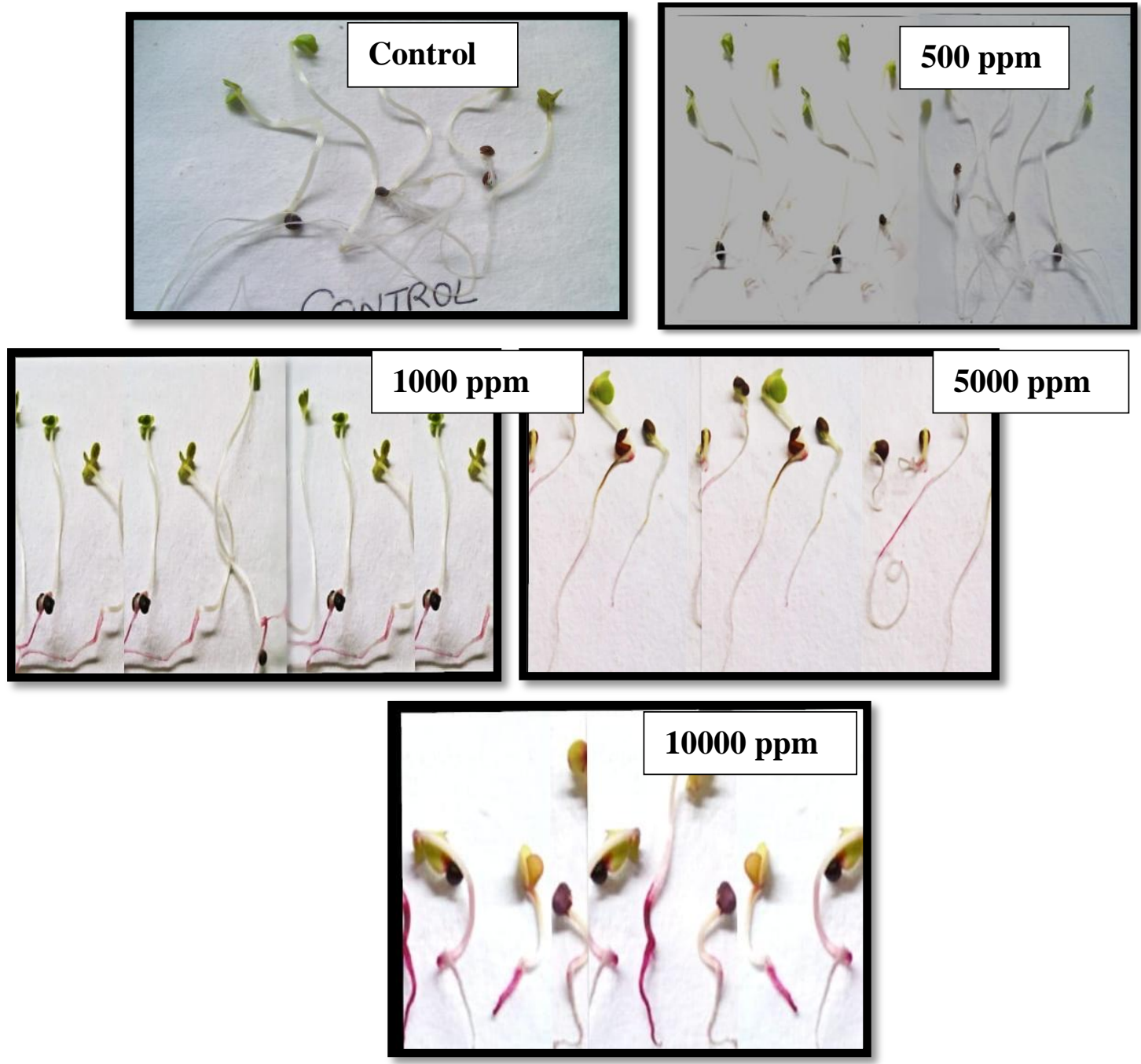

(c) Effect of textile dye on Brassica juncea (Mustard seeds) germination Fig3: Effect of textile dye on (a)Vignaradiata(Moong), (b) Triticumspp (Wheat)and (c)Brassica juncea (Mustard seeds) germination 
Since the decolorositaion of Pigment Red 23 by Pseudomonas spp was seen more it was used for seed germination to check its toxicity after decolorisation. The effect of the decolorized dye was checked by checking the germination pattern of Vigna radiate (Moong), Triticum spp (Wheat) and Brassica juncea (Mustard) seeds (Fig 3). Different parameters were used, among which it was seen that when Pseudomonas spp was autoclaved and applied on the seeds it effectively showed $100 \%$ germination in each type of seed used. The results obtained showed (Table 6) that decolourisation of the dye resulted in reduction in the toxicity of the dye. Hence when Pseudomonas spp was used to decolorize the textile dye Pigment Red 23, it not only decolorized it but also reduced its toxicity.

\begin{tabular}{|c|c|c|c|c|c|}
\hline Sr.No & Seed Type & Parameters & $\underset{\%}{\text { Germination }}$ & $\begin{array}{c}\text { Average } \\
\text { shootlength }(\mathrm{cm})\end{array}$ & $\begin{array}{c}\text { Average } \\
\text { rootlength } \\
\text { (cm) }\end{array}$ \\
\hline \multirow[t]{5}{*}{1} & $\begin{array}{l}\text { Vigna radiate } \\
\text { (moong seed) }\end{array}$ & Water control & 100 & 14.44 & 13.64 \\
\hline & & Dye & 100 & 10.46 & 6.74 \\
\hline & & Autoclaved dye & 100 & 10.04 & 4.56 \\
\hline & & Inoculated/autoclaved & 100 & 14.0 & 6.07 \\
\hline & & Inoculated/centrifuged & 100 & 11.3 & 7.5 \\
\hline \multirow[t]{5}{*}{2} & $\begin{array}{l}\text { Brassica } \\
\text { juncea } \\
\text { (mustard } \\
\text { seeds) }\end{array}$ & Water control & 100 & 5.352 & 7.72 \\
\hline & & Dye & 100 & 4.46 & 6.28 \\
\hline & & Autoclaved dye & 100 & 4.3 & 4.14 \\
\hline & & Inoculated/autoclaved & 100 & 5.55 & 10.45 \\
\hline & & Inoculated/centrifuged & 100 & 4.877 & 5.65 \\
\hline \multirow[t]{5}{*}{3} & $\begin{array}{l}\text { Triticum spp } \\
\text { (wheat) }\end{array}$ & Water control & 100 & 7.63 & 10.30 \\
\hline & & Dye & 100 & 7.0 & 8.8 \\
\hline & & Autoclaved dye & 100 & 5.76 & 7.33 \\
\hline & & Inoculated/autoclaved & 100 & 8.77 & 11.6 \\
\hline & & Inoculated/centrifuged & 100 & 8.2 & 8.03 \\
\hline
\end{tabular}

Table 6: Comparison between \% germination, shoot and root length of different seeds using decolorize dye after treatment

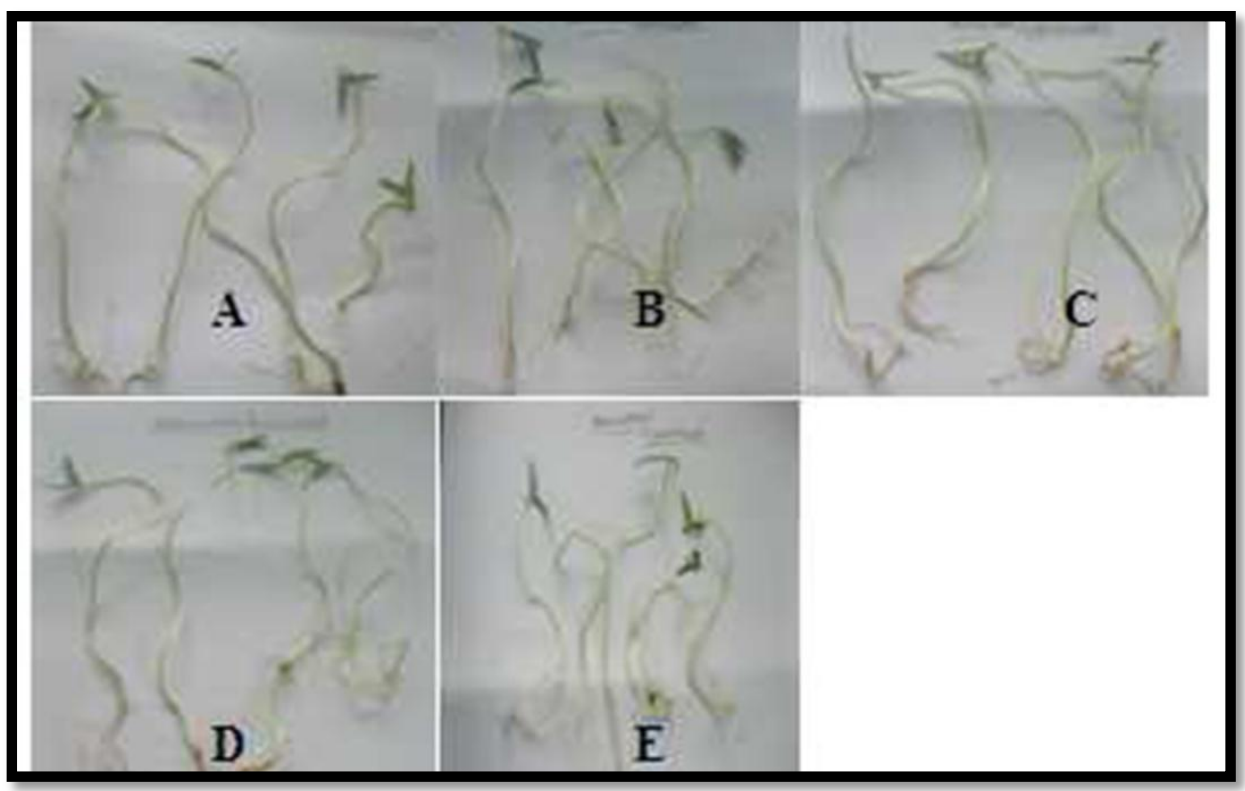

(a) Effect of treated dye sample on Vignaradiata(Moong seeds) 


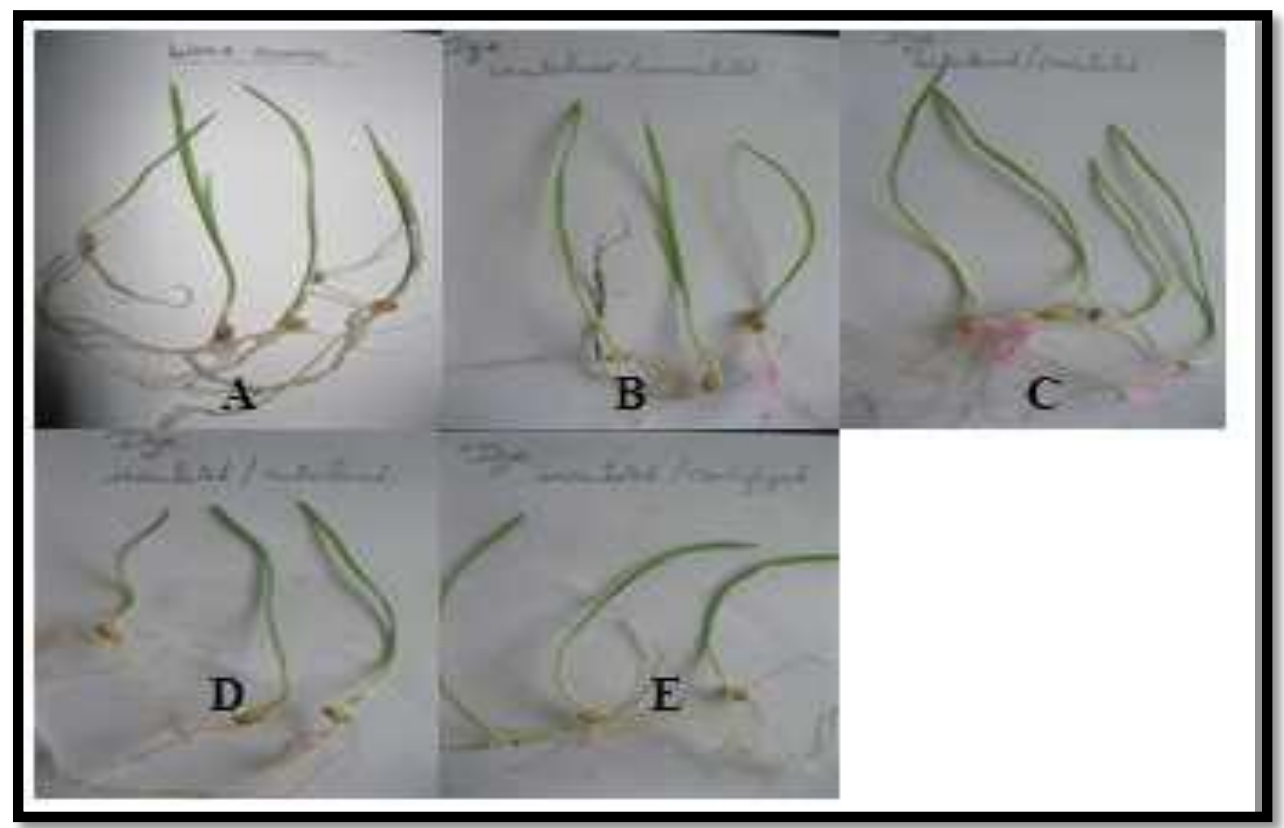

(b)Effect of treated dye sample onTriticum spp (Wheat)

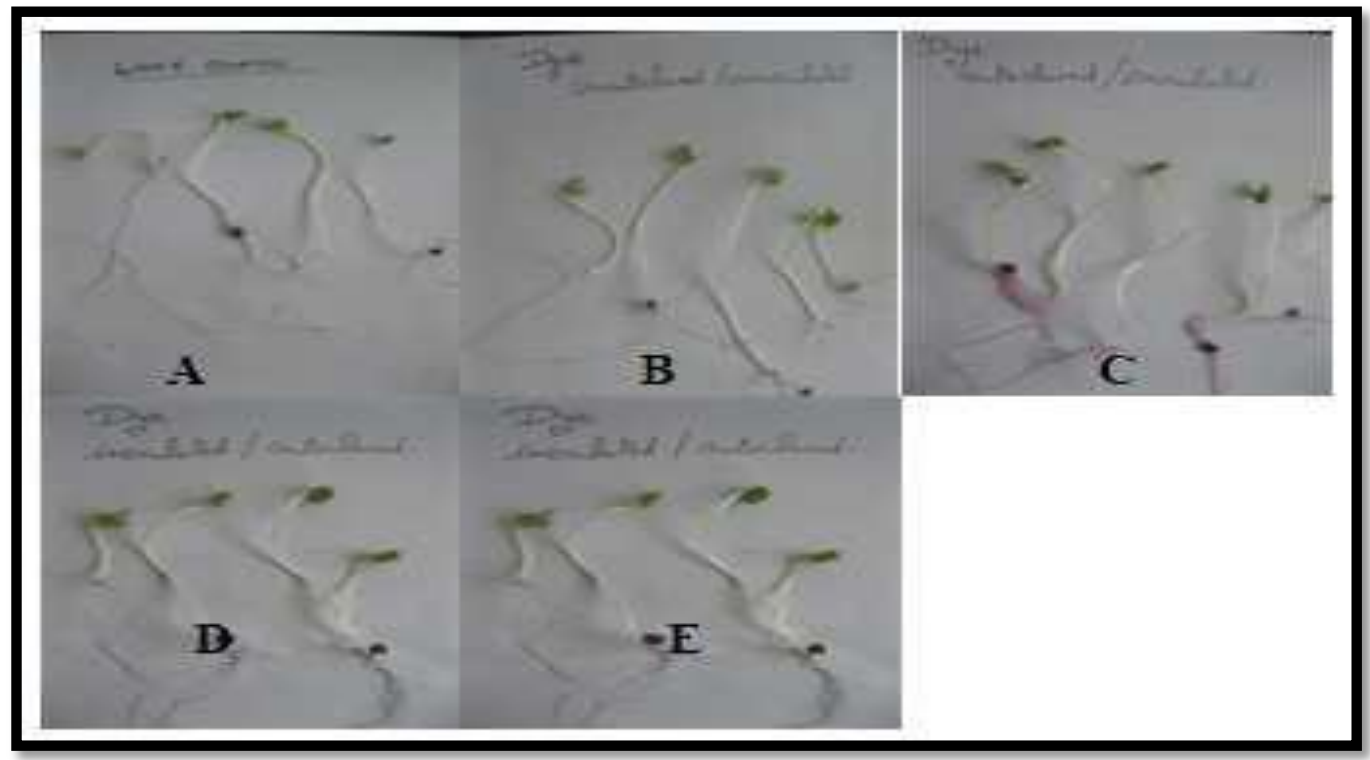

(c) Effect of treated dye sample on Brassica juncea (Mustard seeds)

Fig 3: Effect of treated dye sample on (a) Vigna radiata(Moong seeds), (b) Triticum spp (Wheat), (c) Brassica juncea (Mustard seeds)

A Water control

B $100 \mathrm{ppm}$ of dye in plain water

C 100 ppm of dye in plain water \& autoclaved

D $100 \mathrm{ppm}$ of dye in plain water, inoculated, incubated at $28{ }^{\circ} \mathrm{C}$ for 2 weeks, centrifuged

E $100 \mathrm{ppm}$ of dye in plain water, inoculated, incubated at $28 \mathrm{C}$ for 2 weeks, autoclaved

\section{CONCLUSION:}

Thus from the current study, it can be concluded that the physico-chemical properties of the textile effluent used were comparatively more than the recommended NEQS standard, indicating that the 
effluent needs to be treated before discharging it into the environment. The three isolates Pseudomonas spp, Klebsiella spp and Bacillus spp have the ability to degrade the textile effluent containing dye effectively and also degraded the biological satins upto 100ppm. From the bioassay for toxicity, it can be concluded that as the concentration of dye increases it results in

\section{ACKNOWLEDGEMENTS}

We wish to express our sincere thanks and gratitude to Principle \& Head of the department of Microbiology Dr. SnehalAgnihotri, Dr. D. Y.

\section{REFERENCES}

1. SaranrajP, Bacterial biodegradation and decolourization of toxic textile azo dyes, African Journal of Microbiology Research, Vol. 7(30): 3885-3890, ( 2013).

2. Kaur A, Vats S,Rekhi S, Bhardwaj A, Goel J,Tanwar R S and Gaur K K, Physico-chemical analysis of the industrial effluents and their impact on the soil microflora, Procedia Environmental Sciences, 2:595-599, (2010).

3. Ahmed $\mathrm{T}$ F, Sushil $\mathrm{M}$ and Krishna M,Impact of Dye Industrial Effluent on Physicochemical Characteristics of Kshipra River, International Research Journal of Environment Sciences, 1(2): 41-45, (2012).

4. Rajeswari K,Subashkumar $\mathrm{R}$ and Vijayaraman K,J. Microbiol. Biotech. Res., 3 (5): 37-41, (2013).

5. Varunprasath $\mathrm{K}$ and Daniel A N,Comparison Studies of three freshwater Rivers (Cauvery, Bhavani and Noyyal) in Tamilnadu, IndiaIranica. J. Energy Environ., 1: 315-320, (2010).

6. Suteu D, Zaharia C, Bibla D, Muresan A, Muresan R and Popescu A, Decolourization wastewater from the textile industry- physical methods,

\section{ISSN 2455-6378}

increased toxicity to seed germination as compared with lower concentrations. Toxicity of the degraded dye indicates that after decolourization the toxicity of the dye was reduced and thisproperty of these bacterial isolates shows a potential that can be utilized for the bioremediation of various textile industrial effluents thus saving the ecosystem from harmful effects of various dyes.

Patil ACS College, Pimpri, Pune, for providing the necessary facilities to carry out this research.

chemical methods, IndustriaTextila, 5, 254-263 (2009).

7. Lade H, Kadam A V, Paul D, and Govindwar S, Biodegradation and detoxification of textile azo dyes by bacterial consortium under sequential microaerophilic/aerobic processes,EXCLI J., 14: 158-174, (2015).

8. Tony B D et al., Decolorization of textile azo dyes by aerobic bacterial consortium, Decolorization of textile azo dyes by aerobic bacterial consortium, 63(4):462469, (2009).

9. Khadijah O, Lee K K. and Abdullah M F $\mathrm{F}$, Isolation, screening and development of local bacterial consortia with azo dyes decolourising capability, Malaysian Journal of Microbiology, 5(1): 25-32, (2009).

10. Naphade S R, Durve A A,Bhot M , Varghese $\mathbf{J}$ and Chandra $\mathrm{N}$, Isolation, characterization and identification of pesticide tolerating bacteria from garden soil, European Journal of Experimental Biology, 2 (5):1943-195, (2012).

11. Muthezhilan R, Yogananth N, Vidhya S,Jayalakshmi S, Dye Degrading Mycoflora from Industrial Effluents, 
Research Journal of Microbiology, 3(3): 204-208, (20080.

12. Sriram N and Reetha D, Isolation and characterization of dye degrading bacteria from textile dye effluents, Central European Journal of Experimental Biology, 4 (2):5-10, (2015).

13. Moawad H,Abd el-Rahim W M, Khalafallah M, Microflora involved in textile dye waste removal J. Basic Microbiol., 43 (3): 218-229, (2003).

\section{ISSN 2455-6378}

14. Rehman H N, Athar B H, Textile effluents affected seed germination and early growth of some winter vegetable crops: A case study, Water Air Soil Pollut, 198:155-163, (2009).

15. NEQS- National Environmental Quality Standards, India (2017).

16. Holt JG, Krieg NR, Sneath HA, Staley JT, Williams ST,Bergey's Manual of Determinative bacteriology, Williams and Wilkins U.S.A 9: (1994). 